\title{
Inter-Religious Relationship Between Hindus and Muslims in Lombok
}

\author{
Miftahur Ridho \\ Faculty of Ushuluddin, Adab and Dakwah \\ in the State Institute of Islamic Studies Samarinda, East Kalimantan. \\ miftahuridho@gmail.com \\ Artikel diterima 2 Mei, diseleksi 17 Mei, dan disetujui 8 Juni 2017
}

\begin{abstract}
Despite its heterogeneous population, Lombok is well known for its reputation as Pulau Seribu Mesjid (island of thousand mosques). The idea of thousand mosques reflects the strong notion of Islam as the main identity marker. This, however, often brings uneasiness for both conflict between Muslim and non-Muslim, and between Muslims groups living in the island.This paper, aims at mapping out the triangular relationships between Hindus, Wetutelu Muslims, and Waktu Lima Muslims in Lombok, an island where a significant number of Balinese Hindus live as religious minority among SasakMuslims majority. In this paper, I argue that interreligious relationship between Hindus and WetuteluMuslims is harmonious, while that between Hindus and Waktu Lima orthodox Muslims is marked by hostility. However, the inter-religious relationship between Hindus and the less orthodox Waktu Lima Muslims represent a number of uncertainties.
\end{abstract}

Keywords: Inter-religious Relationship, Plural Societies, Muslims, Hindus.

\section{Introduction}

These days, Inter-religious and interethnic relations occur more frequently since people of different identities interact on a daily basis. However, people of different religions, ethnics, sexes, or other

\begin{abstract}
Abstrak
Terlepas dari keragaman penduduknya, Lombok dikenal luas melalui reputasinya sebagai pulau seribu masjid. Gagasan tentang seribu masjid mencerminkan kentalnya pengaruh Islam sebagai penentu identitas. Sayangnya, hal ini seringkali memunculkan hubungan yang kurang harmonis, baik antara kelompok muslim dengan non-muslim maupun di antara orang-orang Islam sendiri. Tulisan ini, oleh sebab itu, bertujuan untuk memetakan bentuk hubungan segitiga antara kelompok Hindu, Muslim Wetu Telu, dan Muslim Waktu Lima di Lombok, sebuah pulau di mana sejumlah besar kelompok Hindu Etnik Bali hidup sebagai minoritas di antara mayoritas Muslim dari etnik Sasak. Dalam paper ini, saya berargumen bahwa hubungan antar agama, antara kelompok Hindu dengan Muslim Wetu Telu ditandai dengan keharmonisan sementara hubungan antar agama antara kelompok Hindu dengan kalangan Muslim Waktu Lima cenderung ditandai dengan permusuhan. Sementara itu, hubungan antara Kelompok Hindu dengan kalangan Muslim Waktu Lima yang kurang ortodoks ditandai dengan sejumlah ketidakpastian.
\end{abstract}

Kata kunci: Hubungan Antar Agama, Masyarakat Plural, Muslim, dan Hindu.

affiliations are, for many years, neighbors living in the same neighborhood, studying in the same school, or merely attending the same sports clubs. Thanks to the rapid and ever-growing development in areas of information technology, people 
from different part of the globe today have more opportunities to interact than people from several decades in the past could only imagine. It brought into stage the possibility to have more identity markers, and itbroadens the spectrum of inter-religious and other inter-relation contexts. Unless managed successfully, the plural nature of modern society may drive people into conflicts. However, diversity amongst people living in the same social environment can also play important role as social capitals to ensure general wellbeing and harmony.

In Indonesian settings, social interaction, within which people of different religious backgrounds is home of a number of contestations involving other identity markers beside religion. It posts numerous challenges to the process of national integration deemed integral part of the state's strategic plans to grasp its ideal future after a long history of being subject of foreign colonial powers. Additionally, as an archipelagic country, national unity plays a substantial role in safeguarding the country from disintegration thus promoting social cohesion through crafting conducive platforms for healthy social interactions is among the most urgent tasks Indonesian leaders should accomplish. Unfortunately, it was the same notion that pushes most of Indonesians into a long history of oppression during most of its post-independent accounts.

Policy chosen bytheIndonesian government, especially during the authoritarian regime of Suharto's new order, to forge and maintain unity of Indonesian plural society put many relatively 'newborn religious traditions' in the country into a potentially hostile competition. The government initiatives intended to put religion into the core of people's identity, therefore, transformed into coercing people to affiliate with one of several official religions.
To make things worse, the government was also ignorant in its attitudes toward the fact that its people were not merely groups of religious adherents with a set of strong and coherent anchored history. In fact, it is a wellknown historical account that inhabitants across the archipelago experienced foreign imperial powers differently as they were divided into several kingdoms pursuing different interests that most of the times found themselves in conflicting and complex relationships. These diverse experiences, in many ways, form the construction of Indonesian religious identity, particularly regarding pattern of relationships involving religions and ethnics. Sasak people of Lombok, for example, experienced the Dutch invasion into the island, in part, as a liberating military operation to release them from a long oppression by the Balinese rulers. Hence, emphasizing religious identity over other social markers would only sharpen the gap between Sasak-Muslim and Balinese-Hindus.

People coming from different religious backgroundstend to embrace different frameworks by which they approach each other in this regard, at least there are three paradigms of interreligious relations, namely exclusivism, inclusivism, and pluralism.Exclusivists reject to acknowledge the possibility of people from different religions to get salvation because they believe that salvation can only be achieved through their religion. Inclusivists, in other hand, believe that their religion is the best way to achieve salvation yet they also acknowledge that people coming from other religions can also reach salvation for the God's mercy is universal.The pluralists, concerning to the possibility of reachingsalvation, argue that every religion has the equal degree of possibility to reach God's salvation. They further claim that every religion is basically pursuing the same God (divine 
reality) and the only thing that made these religions different is the path they chose in pursuing that same salvation (G. Richards, Inter-religious Relations Today, paper downloaded from www.sekty.cz/ www/stranky/studie/15.pdf on 20 April 2015).

Within a broader model of interreligious relation styles, exclusivism and inclusivism are expression of militant attitude of a particular religion towards others. They emerge when a religion is particularistic in its identity and occupied substantial amount of political power. When a religion with a particularistic identity is weak in term of power, it is likely that it will turn into isolationist. People from this religion will not able to approach other people from different religion with such militant attitudeas they could if they occupied strong power. Here, power plays significant part in shaping the way people of different religions interact with each other. Open dialogue as an ideal way for religions to interact each other, in the other hand, emergeswhen a religion with a universalistic identity occupied strong power. It is in this context that pluralism is considered as a prerequisite for building a platform upon which every religion will have equal stand (Johannes A. van der Ven, A Chapter in Public Theology from the Perspective of Human Rights, Journal of Religion, Vol. 86. No. 3, July 2006).

Pluralism as a foundation for an open dialogue of inter-religious relation is usually put on a par position with exclusivism and inclusivism. This positioning put pluralism on a relatively better position comparing to other models. However, pluralism is highly criticized because its rejection to the uniqueness and universality of every religion thus it places itself as a new set of universal values upon which every practices within any religion is measured.

In a plural society, both exclusivism and inclusivism provide a ground for misunderstandings among people of different religions to thrive. To some points, these misunderstanding mayhinder people from engaging in productive ways and these,too, can lead people into devastating conflicts.Exclusivism leaves no room for salvation outside a particular religion. Because of this, it is likely that the exclusivists will perceive other people outside their religion as living in darkness. People outside the exclusivists' religion, in this context, will obviously not getting along with this belief. Inclusivists, instead of acknowledging the inherent values of other religions, tend to uphold the view that people outside their religion can only be saved through their religion. It means that the inclusivists not only maintain their religion's superiority over other people's religion but also place the people outside their religion within salvific discourse external to their religion.

\section{Balinese Hindu in the Sasak Muslim Land: From GumiSasak to the Island of Thousand Mosques}

Historical accounts of Sasak people in Lombok reveal that during the 17 century the Island was an arena of harsh contestation between two powers, the Makassar in the east and the Balinese in the west. Complexities surrounding the root of Sasak aristocracies ruling the island signify that princedoms during that time had experienced dynamic relations with the two prominent powers. In 1640, the Balinese Kingdom of Gel-Gel Dynasty in Bali conquered the island. The Makassar helped the Sasak to overrun the Balinese Kingdom of Gel-Gel and they managed to push the Balinese rulers to western part of the island. However, around 1740, a branch of Balinese Kingdom of Karangasem expanded its territory to Lombok. The Karangasem successfully took over Lombok from the remaining Sasak Kingdom of Selaparang residing in Eastern Part of the island (Hans Hägerdal, 
From Batuparang to Ayudhya, 1998, p. 7076).

In the Karangasemera, the ruling class carried out discriminatory regulations that marginalize the position of sasak indigenous people. Discriminations towards sasak people aimed not only to maintain the possession of resources by the minority ruling class but also to physically distinguish the sasak people so that the ruling class can effectively recognize and control them (Fath Zakaria, Mozaik Budaya Orang Mataram, 1985, p. 83). The Balinese Kingdom of Karangasem controlled the island and its indigenous population along with other groups of ethnic minority through applying caste system, language etiquette, and land ownership (Daud Gerung, Lombok Mirah Sasak Adi: Sejarah Sosial, Islam, Budaya, Politik, dan Ekonomi Lombok, 2011, p. 1324).

A number of discriminatory practices towards Sasak indigenous population resulting from the implementation of the trichotomy of caste systems, language etiquette, and land ownership provided a basis for many Sasak leaders across the island to rebel. However, the Kingdom of Karangasem managed to settle down those rebellions thanks to their relatively stronger military power.In this context, Islam was used as an ideological justification to fight against the Balinese ruling class. Consequently, amechanism to identify the Sasak and exclude other ethnics, mainly Balinese ethnics, had to be established.The new set of classification then started to be codified, and it was done mainly by many tuan gurus (waktu limaMuslim religious leaders) in the island.

In accordance with their efforts to overthrow the Balinese intruders, Sasakpeople of Lombokemphasizedthe term'GumiSasak' as the name of their island that literally means the land of Sasak. The term provides a basis to strengthen the connection between the Sasakpeople with the land thus it allowed them to claim a deeper sense of belonging to the land than their Balinese rivals and other ethnics do. The term 'Gumi Sasak'also functions as a ground in which the Balinese intrusions into the land can be apprehended in a way that it can reinvigorateother sentimentof anticolonial attitudes towards the Balinese rulers. At the same time, the term'Gumi Sasak'enabled the Sasakto create a moreegalitarian identity to compromise with memories of hostile relation among them in the past, especially relations involving conflicts among sasakaristocracies. In this regard, tuan gurus played pivotal role in the unification of Sasakpeople under religious banner of islam (Jamaluddin, SejarahSosial Islam di Lombok Tahun 1740-1935 M: Studi Kasus Terhadap Tuan Guru, (Jakarta: Kementerian Agama RI, 2011).

The Dutch came to Lombok few years after several Sasak leaders in Lombok asked for assistanceto free themselves from the oppressions of their Balinese rulers in 1891.After a relatively short fight, the Dutch conquered the Balinese Kingdom of Karangasem in Lombok and claimed their rights to rule the island. A series of suicide rituals(puputan) by the Balinese royal family placedthe Dutch on a solid footing to claim its status as a new legitimate ruler (W. Cool, With the Dutch in the East: An Outline of the Military Operations in Lombock, 1894).

Following the Dutch invasion in the end of nineteenth century the Balinese in Lombok was further marginalized because the Dutch, unlike in any other parts of Indonesia, built a good alliance with the orthodox Muslims of Sasak. In other parts of the archipelago, the Dutch put the authority of Adat (traditional customs) above the idiom of Islam in order to reduce potential threat the later could invoke yet it was not the case with 
Islam and its relation with Adat during the Dutch period in Lombok (John Ryan Bartholomew, Alif Lam Mim: Kearifan Masyarakat Sasak, Yogyakarta: Tiara Wacana, 2001, 107).

.Under the Dutch rule, Lombok was grouped into the lesser sunda island along with Bali Island. After the Indonesian independence in 1945, Lombok was separated from Bali and, with the island of Sumbawa, comprised a new province of West Nusa Tenggara in 1958 Tim Penyusun, Monografi Daerah Nusa Tenggara Barat, Book. 1, (Jakarta: Departemen Pendidikan dan Kebudayaan, 1977, 54). The separation posed new promises as well as new problems. It opened a set of good opportunities for the Sasak in Lombok to rebuild their identity.

The Dutch policy to put waktulima Muslim in a relatively better position compared to the wetutelu Muslims and Hindusallowed many of the tuan gurus to spread their influences more broadly (Ahmad Fathan Aniq, Lombok in the Eyes of Anthropologists, 2012, 1; downloaded from http://www.e-dokomen.kemenag.go.id on 20 April 2015). Being not in severe conflicting relationships with the Dutch as a new controlling power, the struggle of thetuan gurus of waktu limaagainst the Balinese rulers transformed into disengaging the Sasak from numerous cultural practices perceived as the continuation of Balinese hegemonic influence during the Balinese colonial period. Among the influences of the Balinese in Sasak people that the tuan gurus eager to demolish were religious marker of sanggahs across the island and the caste-like systems of social stratification.

The tuan gurus managed to reduce those influences significantly. In the nowadays Sasak society, the application of social strata on people of different background seems to be shifting from aristocratic caste-like system of stratification to one that relies on social, economic and educational achievements. Previously, Sasak people was stratified into four classes consisted of the king and his royal families, the noble (ningrat), the pruangse or commoners, and the jajarkarang or servants. Later, the tuan guru took the place that was belong to the king and his royal families. The last three classes then merged and formed a sort of new set of stratifications consisting two main classes; the tuan haji and the non-haji. The tuan haji stratum belongs to those who have fulfilled pilgrimage to mecca and those who are economically affluent, while the non-haji consisted of the commoners and those who live below the living standard of the majority (Jamaludin, Sejarah Sosial Islam di Lombok Tahun 1740-1935 M, 2011, xxi-ii. See also, Lalu Muhammad Ariadi, Haji Sasak, 2013, 204).

This relatively new set of markers has gained recognition from most of Sasak people as significant factors to determine statuses of people in their social environment. In this context, Islam contributed to the transformations of social structures related to stratification of people in Sasak society for it is incompatible with the traditional castelike system (Bianca, J. S, Stealing Women, Stealing Men, 2014, 15 (1), 6; retrieved from http://search.proquest.com/docview/1504 068904? accountid=25704). Moreover, the transformation occurred due especially to the emergence of Islam as the religion of the majority together with increasing amount of charisma gained by tuan gurus from their followers (Interview Sasak Noble in Batujai Village, 28 April 2008). ${ }^{1}$

1 To some extent, many discriminatory practices pertaining to the Sasak during the Balinese colonial period persist up until nowadays, especially in areas where aristocracy-like nobility prevail over religious influence of the institution of tuan guru. In the village of Batujai, for example, persons belong to the lower caste are not allowed to build a house perceived better than houses of the nobles. For example, roofs of houses belong to the lower class must be lower than those of the nobles since they have to represent their submission through certain architectural codes codified by the noble as social norms. At the same time, the noble also secured a range of important positions in the community including positions 
However, it was the cultural and religious marker coined by the sanggahs (family temples of the Balinese) that actually marked the Balinese occupation of the island. The tuan gurus, along with the rest of their waktu lima followers, then, constructed a new set of collective identity that placed mosque at the center of its building blocks (Mahsun, Tragedi di Pulau 'Seribu Masjid',Jurnal Antropologi Indonesia, Vol. 63, 2000). Mosque was placed at a diametralposition against sanggahs and other Balinese symbols of hegemony over the island. To win the continued struggle over cultural marker of the island, the Sasak people had no option but to demolish the sanggahs or build more mosques to outnumber the sanggahs and other Balinese symbols.

Later, as the tuan gurus gained more control over the political field in the island, the fate of institutionalized religion like Islam, as it is practiced in Lombok, relies heavily on mosques since they symbolize authoritative structures regulating religious life of Muslims in the island. In this regard, Lombok has its reputation as "the Island of Thousand Mosques" due to a high number of mosques across the island. In 2014, total number of this kind of house of worship has reached 5.233 units $^{2}$ (Bapedda, NTB dalam Angka 2014, 231) and it continues to grow. The emergence of mosques in Lombok setting can be interpreted in several ways depending on stances used. The growing number of mosques across the island is indicative of the growing awareness among people about the importance of religion to their

related to religious aspect of the community. According to social norms in the community, position of Imam in the local mosque belongs solely to the noble. Thus, among criteria to consider someone as a proper Imam like knowledgeable in religious matters or Arabic fluency, criterion of nobility status plays the most significant part.

2 In Lombok, the term mosque corresponds to masjid and santren. The term masjid or mesigit, as many sasak name it, refers to relatively bigger mosque located at the center of a community and function as a place for Friday prayer. Meanwhile, the term santren refers to smaller mosque scattered across the island. The 2014 sensus on the number of mosque in Lombok is likely to exclude the santrens. lives. The same phenomenon can also be interpreted as a symbol of Muslims struggles to construct their collective identity.

Recently, Hindus in Lombok comprises around five percent of the population and it makes them the largest minority group in the Island. Most of the Hindus live in Municipality of Mataram and West Lombok Regency. However, the proportion of Hindus across the Island, comparing to the number adherents of other religions, vary considerably. In Mataram, the Hindus proportion according to latest national census conducted in 2013 reached 15 percent of the total population. In west Lombok regency, the number is quite lower, about 6.5 percent. In East Lombok Regency, however, the Hindus comprise only 0.07 percent. Standing in stark contrast, the same census shows that Muslims in the island comprise $95 \%$ of the total population with more than 3 million adherents (Bappeda, 234-235).

Having been in the Island for many generations, many Balinese descendants developed a new collective identity that distinguishes them from the Balinese in Bali, an island from which their ancestors started their journey to Lombok. The Balinese in Lombok, however, are familiar with the sasak tradition and culture. It, then, opened the possibility for the Balinese in the island to selfidentify themselves as Bali-Lombok. According to Suprapto, the term BaliLombok, as mentioned by many of his informants, emerged as Balinese residing in Lombok interact with the Balinese in the island of Bali either through family gatherings or through others. The later Balinese associate the Balinese from Lombok as 'orang Lombok' which means people of Lombok. This, in many ways, leads many Balinese to accept the new discernable identity contained in the term Balok, acronym for Bali-Lombok, as it 
corresponds to their complex lived reality (Suprapto, Semerbak Dupa di Pulau Seribu Masjid, Jakarta: Kencana, 2013, 75).

A quote from a Sasak prominent figure below can sketch some lights on how contemporary Sasakfigures portray the relation between the term Sasak, Lombok, and the general usage of the term Balinese (orang Bali). A mixture of the three terms resulted in a sort of attitudesblaming the Balinese residing in Lombok for being different with the majority of Lombok population, the Sasak.

Eventhough they have been living in Lombok for hundread years by now, they are (the Balinese descendants) still another ethnic group applying their own customs... despite the fact that between their customs and Sasak customs share manysimilarities... Ethnic identity of the Balinese in Lombokis a blurred identity marked by ambiguity... they have not totally identified themselves as Lombok people, let alone as Sasak (Ratmaja, Referensi Muatan Lokal, Lombok Timur, KSU Primaguna: 2012, 55).

The Balok identity poses a set of new challenges to the Sasak. It defies the claim that sasak has the right of the land merely because they inherited it from their ancestors, the logic which is itself problematic in many ways since among princedoms in the island were involved in conflict long before outside powers came to overrule them. The Sasak, however, tend to maintain the exclusion of Balinese minority through arguing that the Balinese could not accept the fact that they are now belong to the Lombok thus they must, to some degree, reduce their ethnic orientation to Balinese in Bali.

However, following a long interaction between two ethnics, especially through inter-ethnic marriages between people from both parties, another new set of identity emerged. Many of the previously Bali-Lombok ethnic subgroup in the island are now identifying themselves as Hindu-Sasak (Interview with Young Leader from a mixed family of Sasak-Muslim and Balinese-Hindu, 14 April 2015). It is quite possible that substantial changes in terms of education level of the people in the island have contributed this more open relation involving religion and ethnic.

\section{Triangular Relationship between Hindu, WetuTelu Muslims, and Waktu Lima Muslims}

The relationship between Hindu and Muslim in Lombok settings is a plural form of relationship. Plurality relating to inter-religious engagements involving people of the two religions is affected continuously by the inherent diversity within adherents of each religion. Factors such as historical context in which each of the two religions was brought into contact and the later social, economics, and political circumstances that shaped the core normative values informing how people from the two religions should engage each other in their daily life are central to the discussion of Hindusand Muslimsrelationship in Lombok. Therefore, to understand the dynamics of Hindus-Muslimsrelationship in the island is to explore the rich diversity within each religious institution.

Interreligious relationship between Hindusand Muslimsin Lombok revolves around symbols of religion. The waktulima ${ }^{3}$ Muslims put mosque as their religious symbols representing their existence. They build their santren (mosque in smaller size) in order to override the existence of sanggahs ${ }^{4}$. Thus, santrens could

3 Waktu Lima refers to a more orthodox variant of Islam in the island.

4 Santren refers to a small but practical place to perform prayer for Muslim. It is usually built by muslim farmers who must stay all day long in their paddy field so they cannot easily go to the nearest Mosque to perform 
be found almost everywhere, mostly on the paddy fields where most of the Sasak farmers spent their time to work. The Hindus, as most of them are Balinese, use sanggahs and puras to represent their ethnic and religious identity.However, the wetutelu variant of islamin the island shared many of their sacred sites with the Hindus and it places them at the brink of the Hindu-Muslim division.

During the emergence of reformist Muslim movement, the idea of eliminating sanggahs throughout the island found another rationalization. It was during this time that the idea of seribu masjid (thousand mosques) was put onto picture. Seribu masjid is an indonesian phrase that for most of sasak people is an alien concept since the Indonesian Bahasa is the second language of the Sasaks. However, by using the term seribu masjid to identify Lombok as containing a strong religious identity, the reformist Muslims from waktulima tradition managed to fulfill two interlinked functions. First, it confirms the existence of thousand santrens as a cultural resistance of waktulimaMuslims towards the Balinese Hindus' sanggahs. Secondly, it allows the waktulimamuslim to group themselves into a wider sense of islam and connect them with Muslims around Indonesia.

The idea of Lombok as the island of thousand mosques transformed to a more militant form.Leaders of the waktulima Muslims inclined to have a more universal identity of islam. The ambition to bind themselves with Muslims internationally fell on a fertile ground when in 2008 a tuan guru from east Lombok, ZainulMajdi, won the gubernatorial election of west Nusa

five times prayer. Family temples of the Hindus in the Island. It also can usually be found on paddy field owned by Hindu farmers. It is believed that these sanggah will bring luck to the farmers and the land. The different between a sanggah and a pura lies in the size of the two. Pura is much bigger than the sanggah and it serves as a temple for one or more clans consisting of many families. The wetutelu, however, is a more syncretic variant of islam in the Islam. It sometimes combine the teachings of Islam with Hiduism.
Tenggara. Thetuan guru is a grandson of the most respected waktu lima figure in the island, Muhammad Zainudin Abdul Majid.

The government initiated the construction of Islamic center in Mataram in 2010. The prestigious building is just next to the largest mosque in the island, the Masjid Raya at-Taqwaof Mataram.The new Islamic center building was intended to signify the distinct characteristic of Lombok island as the Muslims land despite the fact that many other religions are exist for years. This Islamic center, as the Governor of West Nusa Tenggara claimed, will unite the thousand mosques across the island (Zainul Majdi, Gubernur NTB: "Islamic Center" Induk Ribuan Masjid, on http://www.antarantb.com, retrieved on 20 April 2015). However, theHindus as the largest minority groups in the island have never questioned this proposal despite the fact that the land upon which the Islamic center will be build was a seme(site for ngaben or cremation) for the Hindus. $^{5}$

Militant type of religious relation promoted by many orthodox Muslim leaders who are now in charge, however, is a real danger pertaining to interreligious harmony in the island. It is obvious that the prestigious Islamic Center building will not only strengthen the culture of seribu masjid (thousand mosques) but also dwarf the existence of the remaining thousand puras(temples) and sanggahs.However, after having multifaceted experience, from colonizers to colonized and then to being religious minority group (David Harnish, Defining

5 According to many oral stories from senior people around the construction site, the land in which the Islamic center would be built was a seme (place for ngaben). Almost every local people from older generation are able to recall past memories when they saw bodies of the dead were being burnt in that seme. However, for younger generation, the site was famous for its reputation as a hunted area full of evil spirits. I myself can recall memories when I had to run from my grandmother house to the Great Mosque of al-Taqwa to perform subuh prayer because the only way to get to the mosque was through that area.

Jurnal Multikultural \& Multireligius Vol. 16 $\mid$ No. 
Ethnicity, (Re)constructing Cultur, Journal of Musicological Research, Vol. 24, 2005), Hindus in Lombok seems to accept the seribu masjid culture as a new cultural marker of the island (Mahsun, Tragedi di Pulau 'Seribu Masjid', Jurnal Antropologi Indonesia, Vol. 63, 2000).

\section{Harmonious Relationship between Hindus and Muslims: the case of WetuTelu}

Islam practiced by Muslims in the island, especially by the Muslims from Sasakethnic background, can be classified into two variants; the waktulima and the wetutelu. The waktulimaislam variant is an orthodox tradition anchoring its core teachings to the qur'an and hadith, and to certain degree, promoting the purification of Islam from local traditions considered incompatible with standardized Islam. The wetutelu variant, on the other side, is a syncretic tradition combining ancestor worship, animism, Hinduism, and Islam. Even though pre-islamic believes still have large influences on rituals practiced by most of the waktulimaMuslims, such influences only part a minor contribution to the overall face of the waktu lima tradition.

Relation between wetuteluMuslims and Hindusrepresent a harmonious inter-religious engagement while relation that involvesHindusand the orthodox waktulimaMuslims is likely to represent a hostile one (Gazi Saloom, Dinamika Hubungan Kaum Muslim dan Umat Hindu di Pulau Lombok, Jurnal Harmoni, Vol. 8, No. 30, April-June 2009, 73). This difference is, in part, due to close connection between religious leaders from wetuteluMuslims and Hindu minority. Since both religions are minority in the island, it is very likely that they feel similar fate seeing their culture and traditions being eroded by the hegemonic power of the waktulimaMuslim majority.

\begin{tabular}{l|l} 
HARMONI & Januari - Juni 2017
\end{tabular}
The wetuteluMuslim along with the Hindus shared many rituals. PerangTopat (rice cake war) in the Temple of Lingsar, West Lombok Regency, is among many celebrations the two religious groups perform together. The Temple of Lingsar, in which the ceremonial war takes place, is shared by both wetutelu Muslims and the Hindus. From the Muslims' perspective, the ceremonial war is their ritual to commemorate the wali (Islamic proselytizer) who came to spread Islam for the very first time in the island. The Hindus, on the other side, believe that the ceremonial war is rooted to the very ritual of Hinduism, which is the ritual of Pujawali (Erni Budiwanti, Balinese Minority versus Sasak Majority, Journal of Heritage of Nusantara, Vol. 3, No. 2, December 2014). Despite both groups label different meaning to the ceremonial war, it is interesting to note that both parties shared a common understanding that the ritual itself cannot be accomplished without both parties involved.

Moreover, religious leaders of wetutelu tradition had proposed to the Hindu community in the Island to be accepted as part of Hindu tradition in the island. However, the pedandas, religious leaders of Hindu, rejected it (Mustain and Fawaizul Umam, Pluralisme Pendidikan Agama dan Hubungan Hindu-Muslim di Lombok, LKIM and IAIN Mataram: Mataram, 2005, 105) ${ }^{6}$. The proposal was rejected due, in part, to political reasons of the pedandas that are unwilling to be involved in potential direct confrontations with the waktulimaMuslim leaders, the tuan gurus. The wetuteluMuslims has long been considered mad'u, target of proselytizing by the waktulimaMuslims thus any occurrence indicating a presence of other rivals targeting the same subject will only trigger fierce responses. The rejections also confirmed the identity

6 According to one of his informant, a Hindu prominent figure in Lombok, Mustain wrote that this meeting was held in Mayura around 1963 and was attained by at least 400 pemangkus of wetutelu. 
of Hinduism in the island as a nonproselytizing religion thus duplicating the number of adherent is not on the tasklist.

\section{Uneasy Relationship between Hindu and the Orthodox Waktu Lima}

Employing religious identity as an important social marker in society is among many strategies utilized by the Indonesian government to ensure national integration. The government's initiative to deal with religious diversity of its citizens through acknowledging only six official religions, therefore, is a continuation of its strategy to control people activity effectively. Consequently, adherents of indigenous religions are required to choose one of those official religions since bearing a religious identity is compulsory for everyone in the country. In this context, the adherents of wetutelu religious tradition are gradually forced to affiliate with Islam (Suprapto, Membina Relasi Damai Antara Mayoritas dan Minoritas,Jurnal Analisis, Vol. XII, No. 1, July 2012, 27).

Nationwide, building of houses of worships and religious defamations are factors considered the main causes to trigger conflict among people of different religious backgrounds in Indonesia. However, since 2005, the prevalence of conflict involving people of different religion in the country tends to decline yet main factors, religious defamation and building house of worship, invoking them remain the same. Furthermore, these relatively new forms of inter-religious conflicts are smaller and more localized in nature. They are also claiming fewer casualties although they occur more frequently (David Cohen et al, Keeping the Faith, Depok: Human Rights Resource Center, University of Indonesia, 2015, 180).
Exclusivist standpoint regarding religion as portrayed by orthodox waktulimaMuslims does not merely reflect any formal affiliation with forerunners of transnational ideology such as the salafi organization. In fact, the waktulima orthodox muslims have some record on expelling and attacking the salafi community in west Lombok. The orthodox Muslims in Lombok tend to form militant types of inter-religious relations because, perhaps, they possess significant political power.The waktulimaorthodox Muslims approach other people of different religions outside Islam and people of different sects within Islamic tradition with an unfriendly manner. This militant attitude can also be traced in the way possession of political power shaped the attitudes of many orthodox waktulima leaders regarding ahmadiya minority in the island (Mahaarum Kusama Pertiwi, Reclaiming Minority's Freedom of Religion or Belief in Indonesia, Master Thesis, University of Oslo, 2014, 7). ${ }^{7}$

The local tuan gurus across the Island, in general, play a major role in disseminatinginformation concerning the fatwa of MUI (Board of Ulama of Indonesia) on the religious status of Ahmadiyah in simple and emotional language so that their umma could understand it more easily. Unfortunately, provocative sermons preached by the tuan gurus had led many Muslims in Lombok to commit a number of violent

7 Ahmadiyah's first arrival in Lombok was in the 1970s. Since then, the ahmadis live in a relatively peaceful atmosphere among the majority of waktulimamuslims. When MUI (board of Ulama of Indonesia) issued a fatawa condemning ahmadiyah as a deviant religious sect in 1980, the majority of waktulimamuslims are still hesitant to show their unwillingness to live along with the ahmadis. Around the end of new order era in 1996, a tuan guru in east Lombok delivered a provocative sermon condemning theological deviations of the ahmadi sect and called for the mass to attack its followers. It was, however, a failure attempt due to political circumstance during the new order regime of President Soeharto. When new order of Soeharto eventually collapsed in 1998, a combination of agitation of many tuan gurus and mass media information about similar attacks against the ahmadi sect in Java led many waktu limamuslims to attack and exile their fellow ahmadi neighbors.

\begin{tabular}{l|l} 
Jurnal Multikultural \& Multireligius Vol. 16 & No.
\end{tabular} 
attacks to facilities belong to ahmadis of Lombok. Such a number of vandalisms were believed to be manifestation of jihad against enemy of islam who tried to tarnish the theological purity of the ummah (Erni Budiwanti, Pluralism Collapses, ARI Working Paper, No. 117, May 2009, 17. Retrieved from www.ari.nus.edu.sg/pub/ wps.htm in 20 April 2015).

Pertaining to inter-religious relationship involving hindu and muslim in Lombok, the Hindu minority amidstthe orthodox waktu limaMuslimscommunity will likely to find themselves trapped in a hostile relationships. Main factor marking this hostile interreligious relationship is the unwillingness of SasakwaktulimaMuslims to live with the Hindus in which both adherents of the two religions can express their religious symbols publicly. It seems like symbols of Hinduism have no place to exist in public sphere where the waktulimaorthodox Muslims is in charge.

An example of this unwillingness to live with Hindus' symbols can be seen in one of the largest disputesover a planned renovation of a temple in northern Lombok. In 2007, when a Balinese Hindu community was renovating a Temple, a group of waktulimaorthodox Muslimsissued a threat saying that should the construction continue they would, by force, stop the construction process. Threat from this orthodox Muslimsorganization, however, was perceived as a support to the man of the regency who, in the name of preventing conflict between Muslims and Hindus, had issued an official letter ordering those working in the construction site to stop their work few months earlier (Kari Telle, Vigilante Citizenships, Bijdragen tot de Taal-, Landen Volkenkunde, Vol. 169, 2013, 183-184).

The idea behind the rejection of that construction was based on the firm claim of many tuan gurus pertaining to the symbolic value of Lombok as the island of thousand mosques'(pulauseribu masjid). The new temple, after the renovation, was perceived as an insult to the Muslims in the island since it would destroy the reputation of Lombok as 'pulauseribu masjid' (the island of thousand mosques). Tuan Gurus involved in the rejection of the temple's reconstruction claimed that Muslims in Lombok are very tolerant. Many tuan gurus also claimed that the Muslims had no problem with Hindus performing their rituals in many temple across the island. However, it was the perceived magnitude of the temple after being renovated that ignited such a hostile resentment from Muslims in the island (Kari Telle, 200-1).

The rejection suggested that the Muslims are not willing to accept it if the Hindus' pura (temple) are placed on a par position with their mosques. The Hindus' pura will only be tolerated as long as it exists under the shadow of thousand mosques culture. It placed the Hindus in the island on a vulnerable position prone to experience discriminatory practices.

In this regard, Murba claimed that the discriminations towards Hindu minority have exacerbated since the fall of Suharto's new order regime that opened the gate for many Sasak leaders in the island to reformulate and redefine policies concerning to indigenous population(puteradaerah). In this case, the idea of Sasak as indigenous people of Lombok was almost taken for granted. Since most of the Sasak leaders are orthodox Muslims, any practice relating to Hinduism has always been placed under keen restrictions. According to Murba, the situation of Hindu minority in Lombok since the beginning of the reform era following Suharto's fall, especially in Praya municipality, is marked with intimidations relating to religious practice, discriminatory regulations in bureaucracy, discrimination in economic fields, and injustice in the distribution of 
teacher of religion in state-funded schools (I Nyoman Murba Widana, Munculnya Resistensi Masyarakat Hindu Etnis Bali di Kota Praya Lombok Tengah, Widya Sandi, Vol. 5, No. 6, Mei 2014, 336-383).

A more militant attitude towards Hindus can be found among young generation within orthodox waktulimaMuslims. Since they are more likely to have their education in Islamic boarding schools led by orthodox waktulimatuan gurus, they are more prone to become victim of a number of unsympathetic sermons. Their hostile attitudes towards Hindus can escalate from unwillingness to live with symbol of Hinduism up to being unwilling to live with people of Hindu religion. A comment from a student residing in a West Nusa Tenggara Province statefunded dormitory in Yogyakarta below may reflect this kind of militant attitudes:

In this dorm, hindu students are never allowed to stay. Should they insist to stay, we will definitely kill them. (Interview with Sasak Students in West Nusa Tenggara State-Funded Dorminory, Yogyakarta, 2 July 2015).

It is, of course, a sad fact that the young generations of SasakMuslims represent such hostile reaction when asked about the possibility of a Hindu fellow from Lombok to stay in a state-funded dormitory.Many of the Hindu students from Lombok, however, accepted this phenomenon as taken for granted and they simply ignore this situation. To make things worse, this hostile attitude towards symbols considered as representing Hinduism can take another form. As many Sasakstudents from Lombok interact with each other outside the island during their stays outside the island, ethnicity as a distinct social marker emerged more strongly.
When mixed with religion, the ethnic orientation of Sasakcan further strengthen the hostile attitude towards Hindus since in Lombok the later religion has long been associated with Balinese ethnic identity. The excerpt below sheds some lights on how the hostile attitude towards Hindus develops through interactions among youth Sasakfrom orthodox waktu limaMuslims, and how those interactions can lead to real hostile actions when these young Sasak Muslims come home to their villages in Lombok.

Now we are planning to destroy the main gate (entrance) to our village because its architectural design is similar with a pura. We hate it so much (Interview with Sasak Students in West Nusa Tenggara State-Funded Dorminory, Yogyakarta, 2 July 2015).

\section{Uncertain Relationship: Hindu and the Less Orthodox Waktu Lima}

In the process of converting the wetutelu adherents into the waktulima, many animistic aspects which distinguishes the wetutelu religious traditions are not disappear. Instead, following the conversion led by tuan gurus of waktu lima, a new forms of syncretism emerged. Symbols of the potential power of ancestor spirits considered central to wetutelu system of cosmology are substituted by ones that are more likely to be accepted by the majority of waktu lima traditional Muslims. In this context, tuan gurus play a pivotal role as figures capable of mediating people with sources of extraordinary power outside the humanly world. They successfully took the places previously belonged to the pemangku (religious leader) of wetutelu religious traditions (Karri Telle, Spirited Places and Ritual Dynamics among Sasak Muslim on Lombok, Anthropological Forum, Vol. 19, No. 3, November 2009, 291). 
However, there exist many stark differences between wetutelu and waktulima variant of Islam in Lombok. The two variants not only differ in minor issues but also differ in many principal matters. In the wetutelu Islam system of belief, humans are believed as incapable of worshiping God directly. Instead, they would need the ancestor spirits as media to connect them to the divine one. However, only pemangku or kyai could establish a connection to interact with the ancestor spirits living in a different realm. As a result, adherents of wetutelu Islam would need the pemangku or kyai (religious leaders mainly function as mediator between human and the spirits) to communicate with their ancestor spirits (M. Ahyar Fadly, Islam Lokal, Lombok Tengah, STAIQ Press: 2008, 45).

Practicing religion for the wetutelu seem to be merely a set of cultural expressions of Sasak indigenous people to maintain local traditions instead of practicing standardized Islam acknowledged by the majority of Indonesian Muslims. Religious rituals performed by the wetutelu Islam adherents, therefore, are perceived as deviations by their waktulima counterpart. The tuan gurus, prominent religious leaders of waktu lima variant of islam in Lombok then considered many of those rituals as heresies and classified those who practiced them as heretics (Erni Budiwanti, Islam Sasak, Yogyakarta: LKiS, 2000, 199-200).

Along with the intensification of Islamic proselytizing by tuan gurus of waktu lima Islam variants to their wetutelu rivals, adherents of the later groups continue to shrinking in number. Those who are more loyal to their wetutelu Islam system of believes subsided to certain areas of Lombok, limited especially in the northern parts of the island. Supported by government bodies, tuan gurus penetrated their missionary activities into remaining strongholds of wetutelu Islam adherents that they considered as heretics more delicately by incorporating their $d a^{\prime}$ was(missionary activities)into many official programs so that the remaining unconverted wetutelu could accept it more willingly (Erni, 297-309).

Among the waktulima Muslims themselves, diversity is a norm rather than an exception. It is true especially regarding the way waktulimaMuslims express their religiosity. A number of rituals performed by many of the waktulimaMuslims, to some extent, indicate the presence of new form of syncretism of Islam, Hinduism, and animistic believes that once was thriving in the island. Such a diverse nature of waktulima religious tradition is linked inextricably to the forms of islamization that had happened in the past, particularly to the ways waktu limaMuslims, with the help of government, converted the wetutelu adherents.

For the majority of traditional waktulimaMuslimsliving in Lombok, religion relates mostly to practices around symbolic expressions. In rural areas where people still practice a more traditional way of life, Muslims interpret the existence of puras, house of worship for the Hindus, as symbolic threats to the privilege of their village since people from other surrounding villages will look down on people from villages where many Hindu's sanggahs prevail or, at least, exist (Interview with a Sasakreligious Leader in West Lombok, 17 April 2015). This conception reinforces the existing religious segregation splitting Hindus and Muslims in terms of residential planning and leads many Muslims to preserve their discriminatory attitudes towards Hindu minority in their neighborhood.

However, the waktulima Muslims who are more syncretic in their Islamic understanding and still practice rituals that are similar to those of the Hindus, mainly those related to ancestors 
veneration, can build a less hostile form of relationship with the Hindus. Adherents of the two religions, in this regard, may share some tombs as sites of veneration to ancestors as long as the Hindus do not intend to build sanggah or merajan (personal or family temple) around the sites (Interview with a Sasakreligious Leader in Central Lombok, 1 June 2015).

The Muslims view the Hindus' religious rituals as venerating the devas (gods) and that these acts of worshiping devas have nothing to do with rituals performed by the Muslims. The Muslims, at the same time, venerated those tombs mostly to pray for their ancestors buried inside the tombs. Notwithstanding, the Muslims also believe that the spirits of people buried in the sacred tombs could bring them prosperity. Most of the Muslims who are practicing this tombs' veneration argue that they do those kinds of rituals as a 'syarat's (requirement) for their $d u^{\prime} a$ (prayers) to be accepted more easily by the God. This understanding of the potential power of the dead is similar with those believed by the wetutelu Muslims in many senses, especially pertaining to the beliefs of ancestral circle.

Relationships involving Hindus and Muslims pertaining to ancestor venerations via sacred tombs across the island can be regarded as mutually beneficial for both parties involved. The Muslims seem to tolerate the Hindus for

8 Many waktulima Muslims who still practice this kind of rituals use the idea of 'jarisyarat' in many occasions. The idea of 'jarisyarat' that literally means 'as a sort of requirements' is a very flexible concept. Muslims who take water from a sacred lingkuk (well) of Buwun Mas in central Lombok, for example, consider the water as containing magical power for curing illness not because the water itself is inherently magical. Instead, the water is magical because it is a part of a more complex system of ritual pertaining divine powers. One of the most famous analogies for explaining the idea of 'jarisyarat' is using an idea of a man quenching his thirst. A man who is thirsty needs water to quench his thirst yet even though he has enough water with him he must actually drink the water to actually quench his thirst. At the same time, that man believes that only God could quench thirst, not the water. The water is merely a requirement for the God's divine power to work. Interview with several waktulima Muslims who practice syncretic rituals, 28 April 2015. reasons relating to the silsila (genealogy) of both groups. Therefore, even though the two groups of different religions talk to each other during their time in the sites, the Muslims limit their talks to such topics as whose tombs the Hindus are venerating. Answers they get from the Hindus, then, compared to theirs. When they realized that the $\mathrm{dead} / \mathrm{s}$ within the sacred tombs are the same person/s, they, then, started to address each other in a more polite way since the dead/s within the sacred tombs signified their familial ties.

Moreover, the Muslims not only allow them to pray and worship the tombs but also guiding the Hindus who performs such rituals. A young Muslim leader from Bilekedit, West Lombok, who is a grandson of a sacred tomb's mangku in GunungSasak, told me a story of his grandfather who has been serving as mangk $u^{9}$ for years (Interview conducted in 17 April 2015). According to him, when a person comes to the sacred site, he/she will be identified according to his/her religious affiliation. In this case, HinduMuslim division is in charge.

Hindus are advised to ask to the SanghyangWidhi while the Muslim are advised to ask to Allah... It is perceived as normal for it does not break the fundamental codes of Islam... My grandfather himself is a pious Muslim, and he did the Hajj pilgrim to mecca (Interview with a sasak young religious leader in West Lombok, 17 April 2015).

Hindus and Muslims have different views relating to the existence of house of worship. In one hand, Muslims perceive the existence of house of worship as merely representing the number of followers belongs to certain religion.

9 The informant used the term juru kunci (key person) to explain his grandfather's position in Bahasa Indonesia. I think he used this term to signify his grandfather's position as a waktulimaMuslim within wetutelu and waktu lima Muslims divisions. 
In other hand, the existence of house of worship for Hindus in Lombok relates closely to the philosophy of Hinduism especially that of the cosmology regarding sources of water (tirtha). Pura, house of worship for Hindus, therefore, found mostly around sources of water such as riverbanks, natural springs, and around fertile lands across the Island. For Hindus, conception that places house of worships as indicating the number of followers of a certain religion is not quite relevant since many of the puras are located outside the population's residences or far away from the follower's villages (Suprapto, Membina Relasi Damai, 32-33). Consequently, a number of puras across the Island, hence, is likely to generate conflicts involving Hindus and Muslims despite the fact that many of those puras have been exist for centuries.

The following explanation given by an Islamic religious leader, a tuan gurulokal (Jeremy J. Kingsley, Tuan Guru, Community, and Conflict in Lombok, Indonesia, Dissertation, Melbourne, 2010, $85)^{10}$, may sketch some lights on matters regarding to what extent that traditional Muslims residing in villages across the island perceive the existence of Hindu puras, sanggahs, and other symbolic expressions of Hinduism.

... The Hindus in Tempos (name of a village) are allowed to build the eler(paddy huller) in the middle of rice fields within gubukselam in one condition. The building (in which huller machine is placed) must show no signs or symbols of Hinduism. Meaning, the buildings should not be equipped with sanggah (family

10 In his research about the role of tuan guru regarding conflict resolution in Lombok, Kingsley distinguishes between tuan guru lokal and tuan guru besar. According to him, tuan guru lokal refer to tuan guru whose influence is limited to one or several villages. Meanwhile, tuan guru besar refer to tuan guru who have wider influence. The later type of tuan guru may affect the government policies across the Island of Lombok. Usually, tuan gurulokal are those who has studied in the pesantren (Islamic boarding schools) of tuan guru besar. temple) or anything related to signs of religion of Hindu (Interview with a sasak religious leader from West Lombok, 17 May 2015).

By emphasizing distinct terms such as 'gubukbali' and 'gubukselam', religious figures of more orthodoxwaktu lima Islam is trying to justify their unfriendly attitude towards the presence of Hindu minority in their villages. Furthermore, Oral traditions spread among the more traditional Muslims reinforce a number of prejudices toward Hindus in many rural areas in Lombok. In the discourse developed among traditional SasakMuslim in general, the religion of Hindu itself is identical with social deviation. Additionally, the Muslims are likely to associate Hindu as a religion with Bali as an ethnic entity. Hence, when a person from a Muslim community does something considered improper, other members in the community will refer to him/her as 'nyembali' or 'jarijero' which literally mean 'being a Balinese' or 'being a jero'. In this context, the differentiation of gubukbali and gubukselam is supposed to be a just deal for both parties; Hindus and Muslims. ${ }^{11}$

In areas where there are only very few of Hindus or none of the population are Hindu, competition amongst Muslims villagers to emphasize their privilege takes another form placing mosque as the most significant marker of religiosity. In this regard, constructing mosque/s has been considered a sort of competition among villages across the island. The more luxurious the mosque is, the more

11 The term gubuk basically refers to an administrative area under a Desa (a village) thus the gubukbali refers to administrative areas within a village (desa) where the majority of the populations are hindu. Muslims in Lombok have many names for referring to an area inhabited by Hindu communities. In several villages in West Lombok, the Muslims call those areas gubukjerowayan or just gubukjero. In Bongor village where I live, the Muslims call the area inhabited by Hindu community gubukgusti. I think this phenomenon has something to do with historical factors pertaining to the residential policy of Karangasem who placed Hindus of different caste in different areas in the island. 
pride a village could gain thus village with the most luxurious and prestigious mosque will win other surrounding villages. Prominent village figures across the island, therefore, will utilize every resource their village has in order to secure enough fund to maintain the honor of their village by constantly building more luxurious mosque. It then makes mosque buildings, compared to other buildings, among the most deluxe places in the island, mostly in rural areas. ${ }^{12}$

\section{Concluding Remarks}

Interreligious relationship between Hindus and Muslims in Lombok reflects the dynamic interplays of ethnic and religion.Since the majority of Sasakpeople in Lombok are Muslim and most of the Hindus are Balinese, interreligious relationship between people from the two religions intermingles with inter-ethnic relation between Balinese and Sasak. Complexity regarding the relationship between people of these two religions is constantly being shaped by the changing social and political circumstances in the island since the period of Balinese Kingdom of Karangasem up until recently.

12 In Gerung sub-district, West Lombok, fundraising for mosques' construction is performed with the assistance of khatibs (preachers) of the mosque. A khatib will give a sermon about the importance of almsgiving and the qualities of those who give some of his/her wealth for religion. When people started to bring their money to the committee in the mosque, khatib will ask him/her question around for whom the pahala of his/her money would be sent. Then, khatibthrough the mosques' sound system will announce name and other identities of the person who has given his/her money to the mosque and asked all people in the village to recite alfatihah - a chapter on the Qur'an - with intention that the pahala(rewards) of such reciting will go to whom the pahala was intended by the person giving that money. Typical announcement made by the khatib is: Alhamdulillah, amal (money or others considered as almsgiving), (mention the amount of money sent by a particular person) rupiah has been sent by Budi (person's name). This amal is intended by Budi for his grandfather who had passed away hoping that the pahala of this amal could bring goodness for his grandfather in the hereafter. For Budi's grandfather, may Allah bring you goodness because of the berkat of reciting al-Fatihah. The khatib, then, closed his gratitude by saying: jazakumullahi khairan katsiran (May Allah give you better rewards - for reciting al-Fatihah for Budi's grandfather).
Long interaction between Muslims and Hindus during the Balinese period resulted in the emergence of wetutelu tradition. The wetutelu is a syncretic tradition that incorporatesIslam and Hinduism into its animistic teachings. People from this traditions practice rituals that are similar with those of the Hindus. At the same time, they also acknowledge themselves as selam (Muslim) and perform several rituals they consider Muslims' obligations towards God.Furthermore, it seems that the wetutelu people identify themselves as Muslims from the beginning. The important position of several ancient mosques (masjid kuno) in the cosmology of the wetutelu signifies that islam contributes to form a substantial portion of wetutelu teachings.

The later waktulima orthodox Muslims in the island, especially their religious leaders, the tuan gurus, accuse the wetutelu Muslims to be 'incomplete' Muslims and blamed the Balinese for the remaining influences of Hinduism in the wetutelu tradition. With the assistances from the government, the waktulima orthodox Muslims managed to convert most of the wetutelu Muslims into waktu lima tradition. However, the conversion of wetutelu to waktulima variant of Islam did not eliminate practices that marked the wetutelu teachings. Instead, it resulted in a new form of syncretism within those considered waktulima Muslims. Eventually, religious and ethnic diversity within people of Lombok lead to the dynamic triangular relationship between Hindus, wetutelu Muslims, and waktulima Muslims.

Inter-religious relation between Hindus and wetutelu Muslims represent a harmonious relationship. Commonalities in terms of religious expression between these two groups allow them to build good cooperation. The existence of several shared religious celebrations, shrines and 
temples streng then that harmonious relation.The waktulimaMuslims, in other hand, express their religiosity through emphasizing the slogan of Lombok as the island of thousand mosques (pulau seribu masjid). It makes them on a direct cultural confrontation with the Hindus who put sanggah sand puras (temples) as their distinctive cultural and religious markers.Because the waktulima orthodox Muslims secured huge political power in the island, it makes the inter-religious relation between Hindusand the waktulima Muslims represent hostility, uneasiness, and intolerance where the Hindus are forced to accept the new cultural identity of the island defined mainly by the tuan gurus of the waktu lima Muslims.
However, among the waktulima Muslims who are less orthodox and still practice many of the wetutelu rituals like tombs venerations, inter-religious relationship with the Hindus tend to be less hostile yet uncertain. People from both religions interact with each other in such a way that those interactions benefit the Muslims. In one hand, this less orthodox waktulima Muslims reject most of the Balinese Hindus symbolic expressions by emphasizing the 'gubukbali' and 'gubukselam' distinctions.In other hand, they tolerate the Hindus to join with them in rituals deemed important for both groups as long as the Muslims, and not the Hindus, are leader in performing such practices.

\section{Bibliography}

Ahmad Fathan Aniq, Lombok in the Eyes of Anthropologists: A Literature Review on Islam WetuTelu and Waktu Lima, Jakarta: Kemenag RI, 2012. Downloaded from http:// www.e-dokomen.kemenag.go.id on 20 April 2015.

Bianca J. S. Stealing Women, Stealing Men: Co-creating Cultures of Polygamy in A Pesantren Community in Eastern Indonesia, Journal of International Women's Studies, 2014. Retrieved from http://search.proquest.com/docview/1504068904?account $\mathrm{id}=25704$.

Daud Gerung, "Lombok Mirah Sasak Adi: Penaklukan dan Pemutlakan Kekuasaan Bali” in Daud Gering (eds.), “Lombok Mirah Sasak Adi: Sejarah Sosial, Islam, Budaya, Politik, dan Ekonomi Lombok", Jakarta: IMSAK Press, 2011.

David Cohen et al, Keeping the Faith:A Study of Freedom of Thought, Conscience, and Religion in ASEAN, Depok: Human Rights Resource Center, University of Indonesia, 2015.

David Harnish, Defining Ethnicity, (Re)constructing Culture: Processes of Musical Adaptation and Innovation among the Balinese of Lombok, Journal of Musicological Research, Vol. 24, 2005.

Dirk Teeuwen, "Lombok Expeditions 1894: Dutch Military Operations in Lombok", pamphlet, downloaded from http://iae.nl on 26 May 2015.

Erni Budiwanti, Balinese Minority versus Sasak Majority: Managing Ethno-Religious Diversity and Disputes in Western Lombok, Journal of Heritage of Nusantara, Vol. 3, No. 2, December 2014.

Pluralism Collapses: A Study of JamaahAhmadiyah Indonesia and Its Prosecution, ARI Working Paper, No. 117, May 2009. Retrieved from www.ari. nus.edu.sg/pub/wps.htm in 20 April 2015. 
Islam Sasak: Wetu Telu Versus Waktu Lima, Yogyakarta: LKiS, 2000.

Fath. Zakaria, Mozaik Budaya Orang Mataram, Mataram: YayasanSumur Mas al-Hamidy, 1985.

Gazi Saloom, Dinamika Hubungan Kaum Muslim dan Umat Hindu di Pulau Lombok, Jurnal Harmoni, Vol. 8, No. 30, April-June 2009.

G. Richards, Inter-religious Relations Today: Towards a Fourth Paradigm, downloaded from www.sekty.cz/www/stranky/studie/15.pdf on 20 April 2015.

Hans Hägerdal, From Batuparang to Ayudhya: Bali and the Outside World 1636-1656, Bijdragen tot de Taal-, Land- en Volkenkunde, vol. 154, no: 1, Leiden, 1998.

I NyomanMurbaWidana, Munculnya Resistensi Masyarakat Hindu Etnis Bali di Kota Praya Lombok Tengah, Widya Sandi, Vol. 5, No. 6, Mei 2014.

Jamaluddin, Sejarah Sosial Islam di Lombok Tahun 1740-1935 M: Studi Kasus Terhadap Tuan Guru, Jakarta: Kementerian Agama RI, 2011.

Jeremy J. Kingsley, Tuan Guru, Community, and Conflict in Lombok, Indonesia, Dissertation, Melbourne: The University of Melbourne, 2010.

Johannes A. van der Ven, A Chapter in Public Theology from the Perspective of Human Rights: Interreligious Interaction and Dialogue in an Intercivilizational Context, Journal of Religion, Vol. 86. No. 3, July 2006.

John Ryan Bartholomew, Alif Lam Mim: Kearifan Masyarakat Sasak, Yogyakarta: Tiara Wacana, 2001.

Karri Telle, Spirited Places and Ritual Dynamics among Sasak Muslim on Lombok, Anthropological Forum, Vol. 19, No. 3, November 2009.

Vigilante Citizenships: Sovereign Practices and the Politics of Insult in Indonesia, Bijdragen tot de Taal-, Land- en Volkenkunde, Vol. 169, 2013.

Lalu Muhammad Ariadi, Haji Sasak, Sebuah Potret Dialektika Haji dan KebudayaanLokal, Jakarta, Impressa Publishing: 2013.

L. Ratmajadkk, Referensi Muatan Lokal: Lombok Selayang Pandang, Lombok Timur: KSU Primaguna, 2012.

MahaarumKusama Pertiwi, Reclaiming Minority's Freedom of Religion or Belief in Indonesia: Evaluating State Response to the Ahmadiyya Conflict in Lombok, Indonesia, Master Thesis: University of Oslo, 2014.

Mahsun, Tragedi di Pulau 'Seribu Masjid': Konflik Agama atau Perlawanan Budaya?,Jurnal Antropologi Indonesia, Vol. 63, tahun 2000.

Mustain and Fawaizul Umam, Pluralisme Pendidikan Agama dan Hubungan Hindu-Muslim di Lombok, Mataram: LKIM and IAIN Mataram, 2005.

M. Ahyar Fadly, Islam Lokal: Akulturasi Islam di Bumi Sasak, Lombok Tengah: STAIQ Press: 2008.

Official Document of NTB Province, Islamic Center: Program Unggulan NTB, downloadable from http://www.programunggulan.ntbprov.go.id/buku/islamic-center/. 
Suprapto, Membina Relasi Damai Antara Mayoritas dan Minoritas: Telaah Kritis atas Peran Negara dan Umat Islam dalam Mengembangkan Demokrasi di Indonesia, Jurnal Analisis, Vol. XII, No. 1, July 2012.

Semerbak Dupa di Pulau Seribu Masjid: Kontestasi, Integrasi, dan Resolusi Konflik Hindu-Muslim, Jakarta: Kencana, 2013.

Tim Penyusun, Monografi Daerah Nusa Tenggara Barat, Book. 1, Jakarta: Departemen Pendidikan dan Kebudayaan, 1977.

W. Cool, With the Dutch in the East: An Outline of the Military Operations in Lombok, 1894 (first published in 1897), translated by. E. J. Taylor, London: FB \& c Ltd, 2014.

Zainul Majdi, quoted from "Gubernur NTB: "Islamic Center" Induk Ribuan Masjid, on http://www.antarantb.com, retrieved on 20 April 2015. 